\title{
THE IMPACT OF SMALL ENTERPRISE ACTIVITY ON THE REGIONAL DEVELOPMENT. THE CASE OF THE PODKARPACKIE VOIVODESHIP
}

\author{
WPŁYW DZIAŁALNOŚCI MAŁYCH PRZEDSIĘBIORSTW NA ROZWÓJ \\ REGIONALNY. PRZYPADEK WOJEWÓDZTWA PODKARPACKIEGO
}

\author{
Łukasz Grzęda'1, Sylwester Kozak² \\ ${ }^{1}$ Poland, Warsaw University of Life Sciences, Faculty of Economic Sciences \\ e-mail: lukasz_grzeda@sggw.pl \\ 2 Poland, Warsaw University of Life Sciences, Faculty of Economic Sciences \\ Nr ORCID: 0000-0001-9485-6704, e-mail: sylwester_kozak@sggw.pl
}

\begin{abstract}
The goal of the study is to examine the impact of small enterprise activity on the regional economic growth on the example of counties in the Podkarpackie voivodeship. The research has shown that both, the increase in the number of already operating and the number of newly registered small enterprises positively contribute to the economic development of the county measured by the total value of sales and the per capita value sales of production manufactured in a given county, as well as the number of employees employed there. The research also indicates that the volume of production of enterprises located in a given county is positively affected by the increase in realized investment outlays as well as the upward trend in GDP of a given voivodeship. The research is based on the data from the CSO Local Data Bank for the years 2005-2016. Estimation of the models was carried out using panel regression.
\end{abstract}

Keywords: entrepreneurship, regional development, the Podkarpackie voivodeship, panel regression

\begin{abstract}
Streszczenie. Celem pracy jest zbadanie wpływu działalności małych przedsiębiorstw na wzrost gospodarczy w regionie na przykładzie powiatów w województwie podkarpackim. Badania wykazały, że zarówno wzrost liczby już działających, jak i wzrost liczby nowo zarejestrowanych małych przedsiębiorstw przyczyniają się pozytywnie do rozwoju gospodarczego powiatu mierzonego wartością ogólnej i przypadającej na jednego mieszkańca sprzedaży produkcji wytworzonej na terenie danego powiatu, a także liczbą zatrudnionych w nich pracowników. Badania wskazują również, że na wielkość produkcji przedsiębiorstw zlokalizowanych w danym powiecie pozytywny wpływ ma wzrost zrealizowanych nakładów inwestycyjnych, a także wzrostowy trend PKB w całym województwie. W badaniach wykorzystano dane z Banku Danych Lokalnych GUS za lata 2005-2016. Ocenę modeli prowadzono przy użyciu regresji panelowej.
\end{abstract}

Słowa kluczowe: przedsiębiorczość, rozwój regionalny, województwo podkarpackie, regresja panelowa

\section{Introduction}

The SME sector is one of the basic pillars of the regional and country's economic development. The SME sector is one of the most important employers, in particular in less urbanized areas. Small enterprises operate mainly in their own region and significantly contribute to its economy. Their activities are associated with the level of entrepreneurship present in the region and are conducive to the development of innovation and competitiveness of the region. Baumol (1968) states that entrepreneurship is one of the basic factors stimulating economic growth. He believes that human creativity and effective entrepreneurship are particularly important in achieving better economic results. These factors allow accomplishing an optimal configuration of the economic environment in the region capable of boosting the final financial results. For this reason, the proper combination of the institutional economic environment and human skills in business and innovation are the best environment for the successful growth of the local economy (Baumol, 1968).

In turn, Cravo et al. (2015) notice the exis-tence of a strong positive relationship between the level of development of the SME sector and the growth of the region's economy in Brazil in 1980-2004. They also find that for the state of the SME sector, the human capital of its employees is a more important factor than the scale of this sector in a given country or region. Additionally, Lepojevic et al. (2016) 
examining the impact of entrepreneurship on the GDP growth in 22 developed and developing countries at the turn of the 1990s and 2000s state that entrepreneurship is a factor of growing importance for economic development. Its positive impact on the economy is more pronounced in developed than in developing countries. Therefore, it is possible to put forward the thesis that regions that make every effort to develop entrepreneurship can expect dynamic economic growth and improvement in their economic attractiveness.

Taking into consideration these ideas the aim of this paper is to present the results of the study on the impact of the number of already operating and newly registered small enterprises on the economic development of the county. The economic potential of the county is measured by the total and per capita value of sales of production manufactured in a given county, as well as the number of employees employed there.

The research used panel data on the sales volume, the labour market, and the structure of business entities in all counties of the Podkarpackie voivodeship for the years 2005-2016. The source of annual data is the Local Data Bank of the Central Statistical Office. The estimation of the econometric models was conducted using a panel regression with fixed effects.

The remaining part of the paper is structured as follow. The first section presents the analysis of economic literature on the regional development, and the methods applied in the research of the economic state of the Podkarpackie voivodeship. The next one presents results and their discussions. The whole paper is summarized in the conclusions.

\section{Literature review}

A significant number of studies on economic development indicate the existence of a positive relationship between the economic growth and the level of entrepreneurship, the number of operating enterprises and the turnover of the SME sector. Studies on these relationships are conducted both at state and regional level.

Audretsch and Keilbach (2005) note that the level of entrepreneurship present in the society of a region is important for accelerating regional development. They find that the economic activity of society helps the improvement of economic results in the region measured, among others, with the value of work efficiency and its growth rate. They believe that entrepreneurship has a much stronger presence in urban areas. They also show that urban centres create a more favourable environment for the development of entrepreneurship. The society living there is more positive about innovation and more willing to take action exposed to a higher investment risk. Similar conclusions are reached by Audretsch and Fritsch (2002), based on the research on 74 regions in West Germany in the years 1980-1999. They state that regions characterized by a higher level of newly opened enterprises also record higher than average dynamics of economic growth.

Folster (2000), in turn, notes that in most countries, governments and local governments support entrepreneurship and create favourable conditions for opening new businesses, expecting as a result increased employment and selfemployment in their jurisdictions. These conclusions are based on a sample of Swedish companies operating in the years 1976-1995. He also notes that the creation of new small enterprises in Sweden positively affected the level of employment, especially self-employment in the country and in many of its regions.

Holtz-Eakin and Kao (2003) note that in a given state, the entrepreneurship rate is positively correlated with the increase in productivity. This means that a greater number of entrepreneurs in a given state contribute positively to improving its competitiveness and increasing the generated GDP. These conclusions are based on the study on the relationship between productivity (understood as the GDP of a given state by the number of employees) and entrepreneurship (understood as the number of newly opened operating enterprises in a given year) in the 1990s in individual states of the United States.

Research on the impact of entrepreneurship and regional development in Poland has also shown the existence of a similar positive relationship between these values. Huczek (2016) indicates that entrepreneurship and competitiveness are factors of regional development. Entrepreneurship stimulates synergic cooperation of three sectors operating in the region: private-economic, public and civic and accelerates development and increases competitiveness of the region. Ignatiuk (2011), in turn, examining the factors affecting the development of the North-Eastern Poland region, with particular emphasis on companies from the SME sector, notes that small and medium-sized enterprises have a strong influence on economic development in the region. This fact is due to employing a significant number of employees. He believes that in the case of a much lower level of economic development of the region in relation to the rest of Poland, financial support of central and local authorities is necessary to increase the effectiveness of this process.

Miłek (2017), examining the relationship between entrepreneurship and regional development in 2010-2014 on the example of the Świętokrzyskie 
voivodeship, finds that entrepreneurship is one of the key factors improving the region's competitiveness measured with the entrepreneurship rate, the number of registered and unregistered entities.

On the other hand, Płaziak and Rachwal (2015) indicate that economic activity and entrepreneurship in the society are important factors of socio-economic development of the region, especially in countries transforming their economies. Entrepreneurship plays a significant role in accelerating economic growth, generating impulses for structural changes in a given region's economy, as well as mitigating the consequences of structural unemployment through the self-employment of people who became unemployed.

As one of the few economists, Zygmunt (2015) does not confirm the existence of a significant link between entrepreneurship and regional development. Based on the study on the impact of entrepreneurship on regional development in the Opolskie voivodeship in 2002-2012, he states that there is no statistically significant relationship between specific measures of entrepreneurship and the development of the voivodeship.

In turn, Hart and Hanvey (1995), examining the relationship between the numbers of newly established small enterprises and employment growth in three regions of Great Britain in the 1980s, state that small enterprises are of particular importance to this process. However, they point to a certain instability of this phenomenon. After periods of significant employment growth in the SME sector, they note periods of redundancies. They recognize that the lack of long-term positive correlation between the development of the SME sector and the development of the local economy can be explained by the improper promotion of entrepreneurship by local governments and the lack of an appropriate strategy for the development of the SME sector.

\section{Material and methods}

The Podkarpackie voivodeship-

the macroeconomic situation

The main subject of the research - the Podkarpackie voivodeship is located in the southeastern part of Poland, and its capital is Rzeszów. It consists of 25 counties, four of which have city status. In 2016, the voivodeship was inhabited by 2.1 million people, this stands for $5.5 \%$ of the country's population. The majority of the population (about $59 \%$ ) live in rural areas (40\% in Poland) (Figure 1). The voivodship's society is relatively young. In 2005-2016, the share of population aged up to 19 years was significantly higher than in the entire country. In 2016 it amounted to $21 \%$ (20\% in Poland). After three years of negative population growth, in 2016 the number of inhabitants of the voivodeship, similar all over Poland, has not changed. This indicates the improvement of human potential in the last year, giving positive prospects for further economic development.

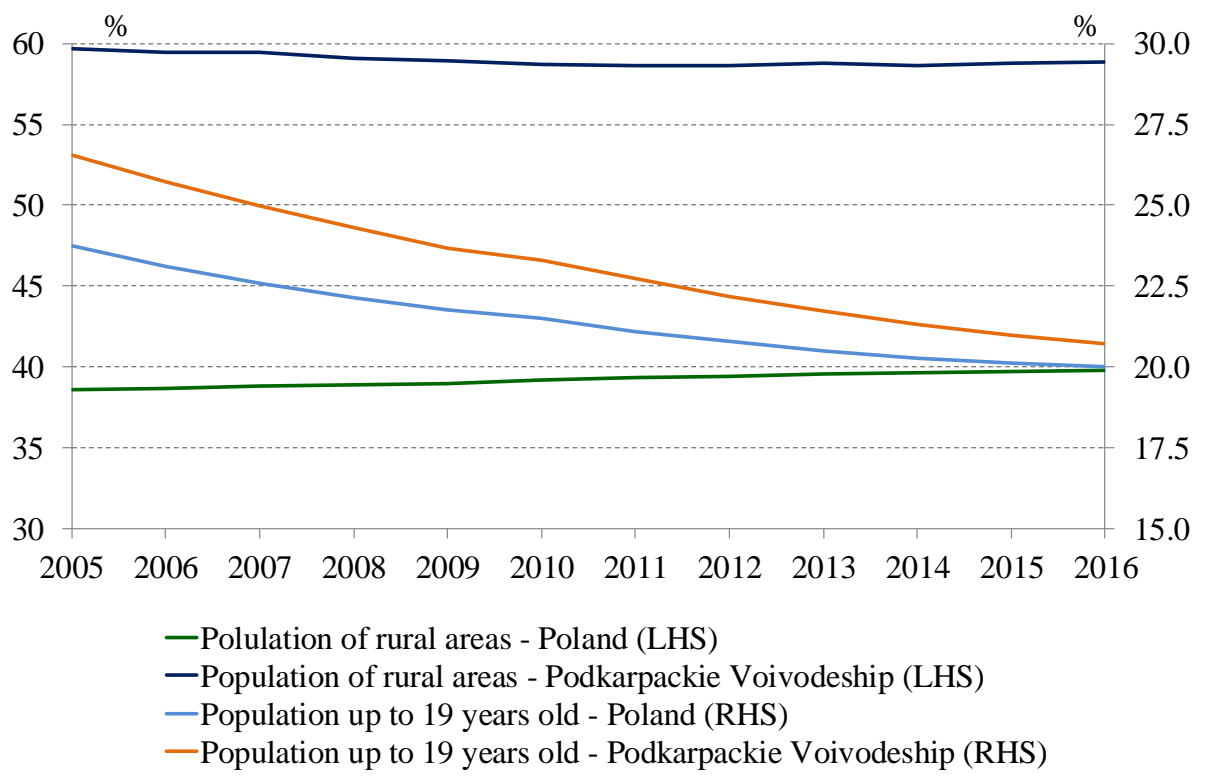

Figure 1. The share of population living in rural areas (LHS) and the share of population aged up to 19 years (LHS) in the total population

Source: own study based on CSO data. 
Household incomes in the Podkarpackie voivodeship are significantly lower than the national average. In 2016, the average monthly salary was PLN 3653 which constituted about $85 \%$ of the national average (PLN 4290). As a consequence, the average monthly disposable income per person amounted to PLN 1474, it means $92 \%$ of the national average. Other incomes and expenditure items were also lower than average in the country. Total expenditure per person amounted to PLN 902, of which expenditure on consumer goods and services was PLN 864, i.e. $80 \%$ of the national average.

Enterprises operating in the Podkarpackie voivodeship reached revenues that place them in $8^{\text {th }}$ position among all voivodships in the country. However, their performance indicators belonged to the average or below average in the country. In 2016, they generated revenues of PLN 92.5 billion, this represents $3.5 \%$ of the corporate income in the entire country. Their gross income and net income of PLN 6.1 and 5.7 billion, respectively, represented slightly higher shares in both the gross and net incomes of the corporate sector in Poland. However, the profitability ratios for gross and net turnover were much more optimistic. In 2016, their values of $6.6 \%$ and $6.2 \%$, respectively, were higher than the national average and equivalent to the highest in the country.

In the Podkarpackie voivodeship the share in the number and value of sales of enterprises achieving positive annual net profit were lower than the national average. In 2016, $81.2 \%$ of enterprises operating in the voivodeship achieved net profit, and their revenues accounted for $76.4 \%$ of the total sales of all enterprises operating there. In Poland, these rates were $81.5 \%$ and $85.7 \%$, respectively. Such performance of the corporate sector in the voivodeship could be associated with the higher costs of running a business in there. In 2016, these costs amounted to PLN 86 billion which stands for $3.5 \%$ of these type of costs in the country.

The Podkarpackie voivodeship belongs to the less developed economically regions of the country. In the years 2005-2016, the value of the region's GDP increased from PLN 39 to 73 billion, which on average constituted around 4\% of Poland's GDP (Figure 2). However, the voivodeship's GDP growth rate was comparable, and in several years higher than the national GDP growth rate. During the analysed period the average GDP growth rate for the voivodship amounted to $5.8 \%$ and was only 0.2 percentage point lower than for the country.

The growing value of GDP with a relatively constant number of inhabitants meant that the value of GDP per capita also had an upward trend (Figure 3). Between 2005 and 2016 in the Podkarpackie voivodeship, similar all over Poland, GDP per capita increased by around $180 \%$. The average annual GDP growth of this indicator amounted to $6 \%$. These figures indicate that the pace of the economic development in Podkarpackie voivodeship is comparable to the pace of development of the core of the national economy.

Entrepreneurship is relatively well developed in the Podkarpackie voivodeship. In 2016, 165 thousand people conducted an individual business activity, which means that on average for every 10,000 about 790 owned their own business (Figure 4). In 2005-2016, annually 13.6 thousand persons registered their business activity in local governments (i.e. 65 entities per 10,000 population). The change in the form of activity or the necessity to withdraw from unprofitable economic activity meant that, in the Podkarpackie voivodeship, annually 10.6 thousand business entities were deleted from the register of the economic activity REGON.

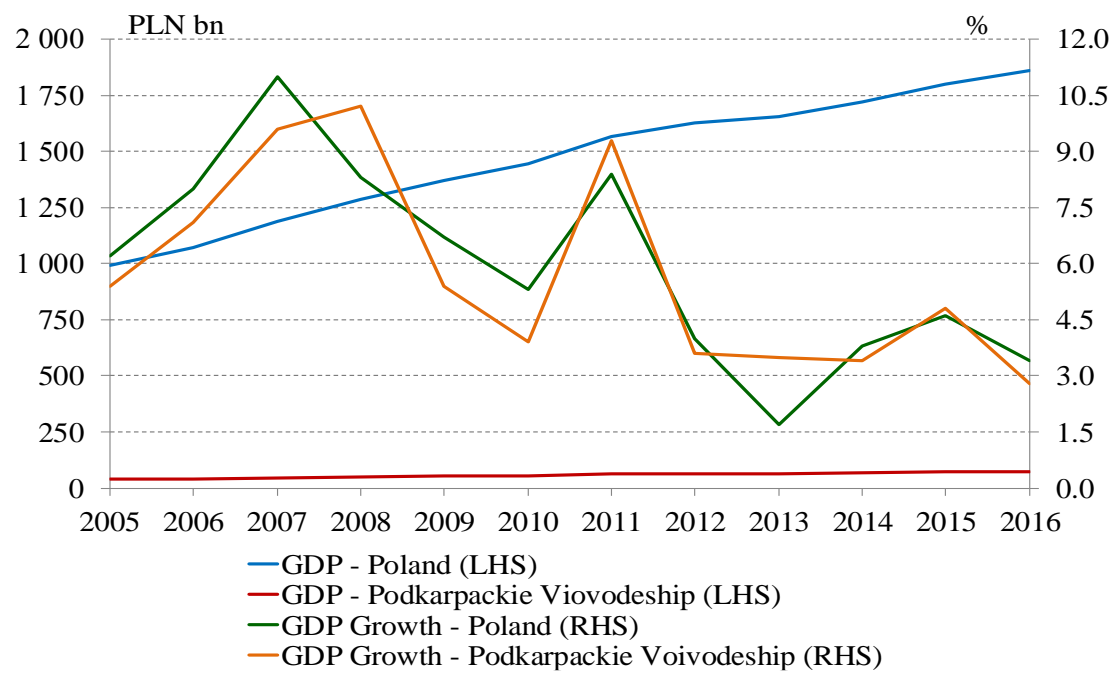

Figure 2. GDP and its annual growth rate in Poland and in the Podkarpackie voivodeship Source: own study based on CSO data. 


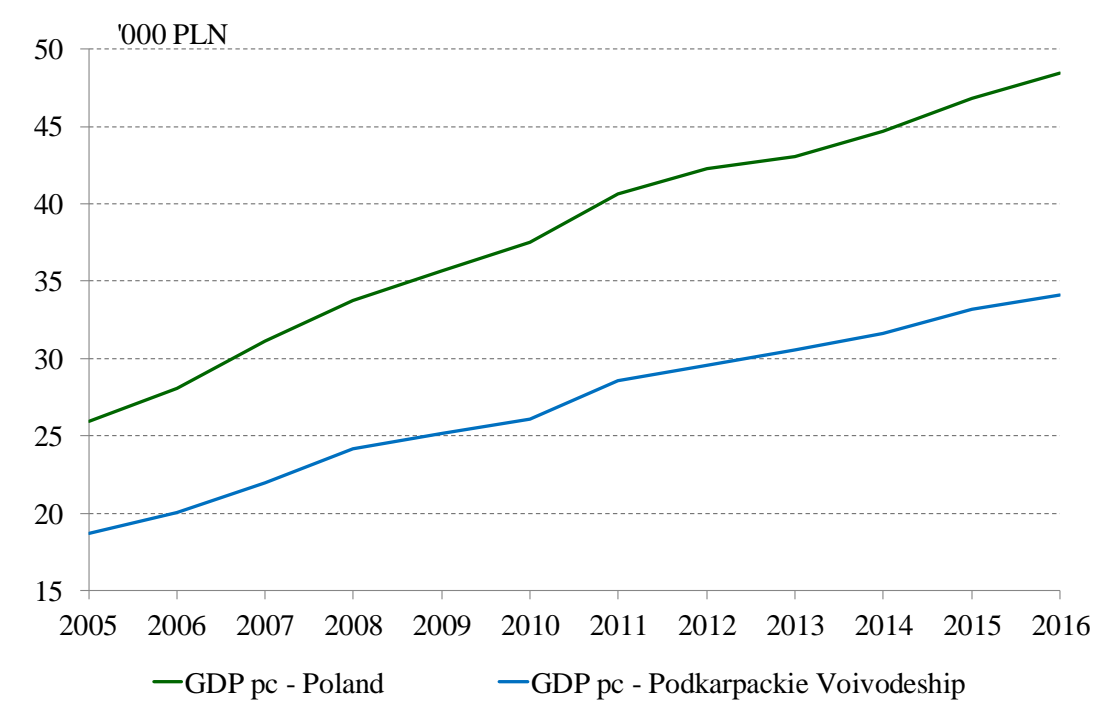

Figure 3. Value of GDP per capita in Poland and in the Podkarpackie voivodeship Source: own study based on CSO data.

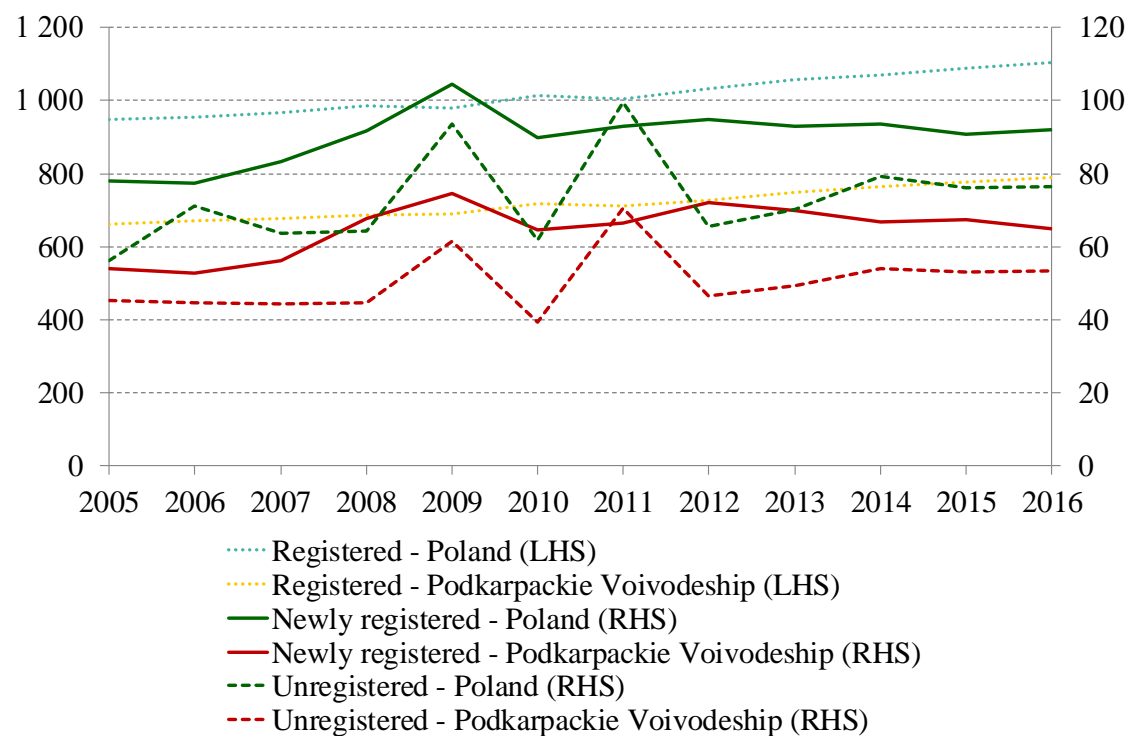

Figure 4. The number of registered, newly registered and unregistered entities from the REGON register per 10,000 population in Poland and in the Podkarpackie voivodeship Source: own study based on CSO data.

Based on methods applied in the previous studies described in the literature, the following model of panel regression was proposed:

$$
Y_{i t}=\alpha_{i}+\beta_{i t} \cdot X_{i t}+\gamma_{t} \cdot Z_{t}+u_{i t}+\varepsilon_{i t}
$$

where:

$Y_{i t}$ - variable describing the level of economic development of the county $i$ and at time $t$ (Production, Production pc, Employment),

$X_{i t}$ - variables describing the county $i$ at time $t$ (Entities, New entities, Investments),

$Z_{t}$ - variable describing the macroeconomic environment in the voivodeship at time $t$ (GDP PDK), $\alpha_{i}, \beta_{i t}, \gamma_{t}, u_{i t}, \varepsilon_{i t}-$ parameter to be estimated.

The estimation was performed using the STATA statistical programme.

\section{Results and discussion}

For testing the hypothesis about the positive impact of the growth of small enterprise activity on the economic development of counties, annual data were used for all counties of the Podkarpackie voivodeship from the Local Data Bank of the Central Statistical Office (BDL) for the years 2005-2016. 
Limited access to the data characterizing the economic and financial situation of counties significantly reduced the number of possible variables representing their economic development or level of entrepreneurship. In the research, the economic situation of a county represents the volume of production sold by enterprises registered in a given county and employing more than 9 people (the variable: Production), as well as the volume of production sold by these firms per capita (Production pc). The last variable, to some extent characterizes the efficiency of enterprises located in a given county. In order to characterize the situation on the labour market, the variable of employment in enterprises registered in a given county was used (Employment).

For every county the level of small enterprise activity was characterized by two variables. The first is the number of all private sector entities per 10,000 inhabitants of the county (i.e. Entities). The second is the number of newly opened business entities per 10,000 inhabitants. This variable reflects the current willingness of the society to start a business activity (New entities).

In turn, innovation and the use of new technologies are represented by the value of investment outlays (Investments). Additionally, the value of gross domestic product generated in the Podkarpackie voivodeship (GDP PDK) characterizes the state of the macroeconomic environment in which all entities operate. The distribution of variables used in the calculations is characterized by descriptive statistics (Table 1).

The results of the estimation of the three model are included in Table 2.

For verification of the reasonableness of choosing a panel regression model with fixed effects, the Hausman test for the three applied equations was carried out. The values of the $\mathrm{x} 2$ statistics indicate that there are no grounds for accepting the null hypothesis and the estimator with the fixed effects should be applied in all three models (Table 3).

Table 1. Descriptive statistics of the variables used in the research

\begin{tabular}{|c|c|c|c|c|c|c|}
\hline Variable & $\begin{array}{c}\text { Number } \\
\text { of observations }\end{array}$ & Average & Median & Standard deviation & Minimum & Maximum \\
\hline Production (PLN mn) & 300 & 1237 & 743 & 1398 & 41 & 7102 \\
\hline Production pc (PLN) & 300 & 1688 & 8848 & 10896 & 642 & 52110 \\
\hline Employment ('000) & 300 & 35.7 & 29.1 & 17.8 & 7.9 & 87.5 \\
\hline Entities & 300 & 719 & 650 & 211 & 444 & 1413 \\
\hline New entities & 300 & 63 & 59 & 19 & 27 & 145 \\
\hline Investments (PLN mn) & 300 & 1913 & 1375 & 1593 & 188 & 8033 \\
\hline GDP PDK (PLN bn) & 12 & 57.2 & 58.2 & 11.1 & 39.3 & 72.6 \\
\hline
\end{tabular}

Source: own study based on CSO data.

Table 2. Results of estimation of the panel regression model

\begin{tabular}{lcccccc}
\hline \multicolumn{1}{c}{ Variable } & Production & t-statistics & Production pc & t-statistics & Employment & t-statistics \\
\hline Entities & $4.013^{\mathrm{a}}$ & 3.83 & $12.49^{\mathrm{c}}$ & 1.714 & $19.01^{\mathrm{a}}$ & 6.98 \\
New entities & $1.58^{\mathrm{b}}$ & 2.29 & $6.827^{\mathrm{c}}$ & 1.812 & $5.239^{\mathrm{a}}$ & 7.92 \\
Investments & 0.294 & 1.21 & $6.396^{\mathrm{a}}$ & 3.49 & $1.982^{\mathrm{b}}$ & 2.11 \\
GDP PDK & $0.001^{\mathrm{b}}$ & 2.09 & 0.028 & 1.16 & 0.001 & 0.30 \\
Constant & $-1266.1^{\mathrm{a}}$ & -6.14 & $-8040.7^{\mathrm{a}}$ & -3.97 & $8743.3^{\mathrm{a}}$ & 8.14 \\
Number of observations (counties) & $300(25)$ & & $300(25)$ & & $300(25)$ & \\
F-statistics & 73.32 & & 86.80 & & 94.36 & \\
Coefficient R2 & 0.432 & & 0.457 & & 0.505 & \\
\hline
\end{tabular}

Source: own study based on CSO data.

Table 3. Results of the Hausman test

\begin{tabular}{cccc}
\hline Statistics & Model „Production” & Model „Production pc” & Model „Employment” \\
\hline X2 & 29.19 & 18.75 & 35.11 \\
\hline
\end{tabular}


The results obtained in the research are in many aspects convergent with the results presented in the previous studies on the impact of entrepreneurship on the regional economic development presented among others by Audretsch and Fritsch (2002), Callejon and Segarra (1999) and Mueller (2007). The value of the production sold positively depends both on the number of already registered and newly registered entities in a given county. An increase by one entity in relation to 10,000 inhabitants could create an increase of PLN 4 million in annual production sold in a given county. On the other hand, an increase by one newly registered entity per 10 inhabitants could increase this production by PLN 1.6 million. The macroeconomic environment in the entire voivodeship also had a positive impact on the value of the production sold. In this case, the increase in the region's GDP by PLN 1 billion contributed to the increase in sales in the county by PLN 2 million.

A similar nature of dependence occurs when the economic development of the county is represented by the production sold per capita. This number is positively affected by the number of already registered entities, newly registered entities, as well as the value of expenditure on investments.

In turn, in the model describing the dependence of the employment level in the county on internal and external factors, with the exception of GDP PDK variable, coefficients estimated for all described variables turned out to be statistically significant (Table 2). The results of the calculations confirm the hypothesis that the increase in activity among small enterprises improves the employment status in counties (consistent to the results of Hart and Hanvey (1995) and Folster (2000)).

\section{Conclusions}

The research covered the state of the economy, labour market and economic activity of small enterprises in the counties of the Podkarpackie voivodeship in the years 2005-2016. The results of the regression analysis of indicators of regional economic development and individual entrepreneurship based on data on individual counties indicate that:

1. The number of registered enterprises in the county is an important factor enabling the increase of the economic potential of the county. The increase in the number of registered small enterprises positively affects the level of the production sold generated by enterprises located in that area, the production sold per capita as well as the number of employees employed in them.
2. The growth of entrepreneurship and the increasing number of newly registered entities contribute to the increase in the economic potential of the county and its competitiveness. The increasing number of newly registered small enterprises has a positive impact on the value of the production sold and the number of employees in a given county. It also improves the effectiveness of enterprises expressed in the volume of the production sold per one inhabitant.

3. The amount of outlays incurred by enterprises for investments in fixed assets has a positive impact on increasing the employment level in the county and helps to improve the county's competitiveness measured as the value of the production sold per capita.

4. The conclusions obtained in the research are convergent with the results of previous analyses presented in the economic literature which indicate a positive impact of entrepreneurship growth on the economic potential and competitiveness of the region.

Additionally the conclusions of the research allow formulating proposals to the regional authorities aiming to accelerate the regional development:

1. In the region it is necessary to create a system supporting the innovation and implementation of the research into the industry. An important pillar of the system should be created by universities operating there (among others, the University of Rzeszów and the Rzeszów University of Technology). The experience of the Rzeszów University of Technology in the master degree programme in the field of the aviation industry should be used. Local and regional authorities should introduce facilities related to the technology transfer and absorption of research into the operation of the SME sector.

2. The example of the Grodziski poviat in the Mazowieckie voivodship could be duplicated where the Mazovian Regional Loan Fund (a nonprofit organization appointed by the Mazowieckie Voivodship self-government) provides low-cost loans aiming to support existing entrepreneurs and those who plan to become one. A similar programme of granting low-cost loans to entrepreneurs starting their business activities is organized by the Lower Silesian Voivodship. Another type of the authorities' support for entrepreneurs is a business incubator. In Gdańsk the programme "STARTER" helps entrepreneurs who start their activity or are not longer than 3 years on the market. Local authorities offer offices for low rent, consultations with specialists in the fields of marketing, law, accounting, as well as support in creating business plans or 
establishing contacts. In order to improve the entrepreneurial situation in the Podkarpackie voivodeship a large number of business incubators should be created, as well as larger support from self-government units in the form of low-cost loans.

\section{References}

Audretsch, D.B., Keilbach, M. (2005). Entrepreneurship Capital and regional Growth. The Annals of Regional Science. 39(3), 457-469.

Audretsch, D., Fritsch, M. (2002). Growth Regimes over Time and Space Regional Studies. 36(2), 113-124.

Baumol, M. (1968). Entrepreneurship in Economic Growth. American Economic Review. 58(2), 64-71.

Callejon, M., Segarra, A. (1999). Business Dynamics and Efficiency in Industries and Regions: The Case of Spain. Small Business Economics. 13, 253-271.

Cravo, T.A., Becker, B., Gourlay, A. (2015). Regional Growth and SMEs in Brazil: A Spatial Panel Approach. Regional Studies. 49(12), 1995-2016.

Foelster, S. (2000). Do Entrepreneurship Create Jobs?. Small Business Economics. 14(2), 137-148.

Hart, M., Hanvey, E. (1995). Job Generation and New Small Firms: Some Evidence from the late 1980s. Small Business Economics. 7(2), 97-109.

Holtz-Eakin, D., Kao, Ch. (2003). Entrepreneurship and Economic Growth: The Proof is in Productivity. Center for Policy Research Working Paper Nr. 50, Maxwell School, Syracuse University.

Huczek, M. (2016). Przedsiębiorczość i konkurencyjność w rozwoju regionalnym. Zeszyty Naukowe Wyższej Szkoły Humanitas. Zarządzanie. 3, 247-257.

Ignatiuk, S. (2011.) Wpływ przedsiębiorstw z sektora MSP na rozwój gospodarczy północno-wschod- niego regionu kraju. Ekonomia i Zarządzanie. 3, $\mathrm{Nr}$ 2, 7-20.

Lepojevic, V., Ivanovic, M., Mladenovic, J. (2016). Entrepreneurship and economic development: a comparative analysis of developed and developing countries. Facta Universitatis Series: Economics and Organization - University of Nis. 13(1), 7-29.

Miłek, D., Kantarek, I. (2017). Przedsiębiorczość w rozwoju polskich regionów. Nierówności społeczne a wzrost gospodarczy. 50, 315-328.

Mueller, P. (2007). Exploiting Entrepreneurial Opportunities: The Impact of Entrepreneurship on Growth. Small Business Economics. 28(4), 355$-362$.

Rachwał, T., Płaziak, M. (2015). Przedsiębiorczy region - zarys koncepcji w świetle analizy roli przedsiębiorczości w krajowej strategii rozwoju regionalnego. Przedsiębiorczość - Edukacja. 11, $37-49$.

Zygmunt, J. (2015). Przedsiębiorczość jako czynnik rozwoju regionalnego na przykładzie województwa opolskiego. Prace Naukowe Uniwersytetu Ekonomicznego we Wrocławiu. 393, 184-192. 